\title{
Phenolic Compounds as Cultivar- and Variety-distinguishing Factors in Some Plant Products
}

\author{
Joanna Klepacka • Elżbieta Gujska • Joanna Michalak
}

Published online: 18 January 2011

(C) The Author(s) 2011. This article is published with open access at Springerlink.com

\begin{abstract}
The aim of the study was to determine whether phenolic compounds in some varieties of buckwheat, winter and spring barley and peas can be used as factors which distinguish selected cultivars and varieties of plant material. It was observed that the content of total phenolics might be useful as a cultivar-distinguishing factor for all the plant materials analyzed, but it was a distinguishing factor for only some varieties. Individual cultivars and varieties were best distinguished by the content of syringic acid. The levels of syringic and vanillic acids were in reverse proportion to the total amount of phenolics soluble in methanol and a positive correlation between syringic and ferulic acid was observed. Moreover, the protein content of plant material was analyzed and a significant $(p \leq 0.05)$ correlation between this component and ferulic and vanillic acids was noted.
\end{abstract}

Keywords Phenolics · Phenolic acids · Buckwheat · Pea · Barley

\section{Introduction}

It is well known that phenolic compounds belong to bioactive components of plant products and have high health-promoting activity [1-5]. Their content depends on many factors such as: climatic and agrotechnical conditions in cultivation and harvesting, ripeness of the material, harvest time, storage conditions, effect of genetic factors

J. Klepacka $(\bowtie) \cdot$ E. Gujska $\cdot$ J. Michalak

Food Science Department, University of Warmia and Mazury,

ul. Heweliusza 6,

10-957 Olsztyn, Poland

e-mail:klepak@uwm.edu.pl and varieties-dependent variability [5, 6]. Plant phenolics can be very generally divided to phenolic acids and flavonoids, which are present in the free and conjugated forms $[4,6]$. Most naturally-occurring phenolic compounds are present as conjugates with polysaccharides and proteins $[1,4,7,8]$.

Cereals and leguminous plants play a major role in human nutrition and are a good source of saccharides, proteins, selected micronutrients and phenolics [1, 9]. Between them, noteworthy are: barley [10], buckwheat [3] (although it is not a cereal grain, it is usually grouped with other cereals because of a similarity in cultivation and utilization) and peas [7]. Grains of barley and buckwheat are used to produce frequently consumed groats and flakes $[3,10,11]$ and pea seeds are consumed by humans principally as green immature seeds $[7,11]$. Phenolic acids are the most important and the largest group of antioxidants in terms of incidence in cereal grains $[6,10,11]$ and peas [7]. They consist of two subgroups, i.e., hydroxybenzoic and hydroxycinnamic acids [5, 9]. The forms of salicylic, phydroxybenzoic, vanillic, protocatechuic, p-coumaric, syringic, ferulic and sinapic acids have been identified in barley grains $[10,11]$. The bran-aleurone fraction of buckwheat contains bound syringic, p-hydroxybenzoic, vanillic and p-coumaric acids [6]. Dueñas et al. [7] reported that the percentage of phenolic acids with respect to the total content of phenolics in the pea cotyledon ranged from 87.99 to $91.57 \%$ depending on the type of variety.

The amount of phenolic content may be varietydependent [10-15], but mainly data concerning the differences between varieties inside one cultivar $[7,8,10,14]$. In literature, phenolics in buckwheat, barley and peas have been determined using different analytical methods. For research purposes, it is important to apply the same method to determine whether phenolics can be used as factors to 
distinguish selected cultivars and varieties of plant material and this was the aim of this study. In addition, the protein content of individual materials and relationships between analyzed components has been determined.

\section{Materials and Methods}

\section{Samples}

Three buckwheat (Fagopyrum esculentum Moench.) varieties, three peas (Pisum sativum L.), three winter barley (Hordeum vulgare L.) and three spring barley were used in this study (Table 1). Samples were harvested in 2005 and collected from the breeding stations in Poland. They were dehulled and ground in a WZ-1 type laboratory mill and analyzed. All extractions and determinations were made in triplicate.

\section{Chemicals}

Standards of catechin, $\alpha$-amylase from Aspergillus oryzae and phenolic acids (ferulic, coumaric, syringic and vanillic) were purchased from Sigma-Aldrich (USA). All reagents and solvents used were of analytical or HPLC grade purity.

\section{Protein Content}

Protein content $(\mathrm{N} \times 6.25)$ was determined by the Kjeldahl method.

\section{Total Phenolics (Soluble in Methanol)}

The total phenolics were determined spectrophotometrically according to Ribereau-Gayon [16] using extraction five times with $80 \%$ methanol, at the temperature of $22{ }^{\circ} \mathrm{C}$, with shaking, the addition of Folin-Ciocalteu reagent and sodium carbonate and then measurement of the absorbance at a wavelength of $720 \mathrm{~nm}$ against the reference sample. The results were expressed as catechin equivalent with a reference curve plotted for D-catechin.

\section{Phenolic Acids}

The phenolic acids were determined by the Pussayanawin and Wetzel method [17]. Phenolic acids were released from investigated plant sources with acid and enzymatic hydrolysis followed by separation with the HPLC method. Samples $(1 \mathrm{~g})$ of each variety were combined with $35 \mathrm{ml}$ $0.1 \mathrm{M} \mathrm{H}_{2} \mathrm{SO}_{4}$ and placed into a boiling water bath for $30 \mathrm{~min}$. Hydrolysis was terminated by cooling in an ice water bath for $10 \mathrm{~min}$ before the addition of $5 \mathrm{ml}$ of $2 \%$ (w/v) suspension of $\alpha$-amylase from Aspergillus oryzae in a
2.5 $\mathrm{M}$ aqueous sodium acetate solution. The samples were incubated at $30{ }^{\circ} \mathrm{C}$ for $1 \mathrm{~h}$ with periodic agitation and then centrifuged at $10,00 \mathrm{~g}$ for $15 \mathrm{~min}$. The supernatant was decanted into a $50 \mathrm{ml}$ volumetric flask and diluted to volume with distilled water. Prior to injection into the chromatograph the samples were filtered through a $0.45 \mu \mathrm{m}$ nylon filter. The extracts were protected from UV light and stored in the refrigerator prior to analysis. The following separation conditions were applied: Hewlett Packard liquid chromatograph; column Supelcosil $150 \times 4.6 \mathrm{~mm}$; mobile phase: a solution of $12 \%$ methanol in a sodium citrate buffer ( $\mathrm{pH}$ 5.4); stationary phase: silica gel of $5 \mu \mathrm{m}$ granulation which was chemically modified with bond aliphatic hydrocarbons with 18 molecules of carbon in a chain; flow rate: $1 \mathrm{ml} / \mathrm{min}$; UV-VIS detector. Coumaric, syringic and vanillic acids were detected at $280 \mathrm{~nm}$ and ferulic acid at $320 \mathrm{~nm}$. Peak identification was based on the retention time by comparison with standard compounds.

Data Analysis

Each experiment comprised three replications. The data were expressed as means \pm standard deviations and were analyzed using Statistica 8.0 statistical software. Significant differences were calculated according to Duncan's Multiple range test. Differences at the $5 \%$ level were considered statistically significant. Correlation coefficients between analyzed seed components were determined.

\section{Results and Discussion}

\section{Protein Content}

The lowest protein content was found in barley cultivars (spring $8.3 \%$, winter $8.5 \%$ ) and the highest in pea seeds (24.6\%) (Table 1). Except buckwheat, there were statistically significant differences in protein content between all the analyzed varieties within the cultivars. Protein content is typical of individual materials and depends on many factors, such as: variety, cultivar, soil- and climaterelated factors, fertilization and others [18, 19]. Similar protein levels have also been reported by other authors [20-22].

\section{Total Phenolics}

The total amount of phenolics ranged from $28.3 \mathrm{mg} / 100 \mathrm{~g}$ in the pea variety Milwa to $288.1 \mathrm{mg} / 100 \mathrm{~g}$ in the buckwheat variety Kora (Table 1). Statistically significant differences $(p \leq 0.05)$ were found between some varieties of the analyzed cultivars. These results are in good accordance with some previously reported data. Zieliński 
Table 1 Selected quality determinants of the analyzed plant products

\begin{tabular}{|c|c|c|c|c|c|c|c|}
\hline \multirow[t]{2}{*}{ Cultivars } & \multirow[t]{2}{*}{ Varieties } & \multirow[t]{2}{*}{ Protein content $[\%]$} & \multirow{2}{*}{$\begin{array}{l}\text { Total phenolics } \\
{[\mathrm{mg} / 100 \mathrm{~g}]}\end{array}$} & \multicolumn{4}{|c|}{ Phenolic acids $[\mathrm{mg} / 100 \mathrm{~g}]$} \\
\hline & & & & Ferulic acid & Coumaric acid & Syringic acid & Vanillic acid \\
\hline \multirow[t]{3}{*}{ Buckwheat } & Kora & $12.3 \pm 0.0^{\mathrm{a}}$ & $288.1 \pm 5.0^{\mathrm{b}}$ & Traces & $2.1 \pm 0.1^{\mathrm{a}}$ & $19.1 \pm 0.5^{\mathrm{c}}$ & Traces \\
\hline & Luba & $12.2 \pm 0.1^{\mathrm{a}}$ & $263.8 \pm 16.7^{\mathrm{a} . \mathrm{b}}$ & Traces & $2.4 \pm 0.0^{\mathrm{b}}$ & $16.7 \pm 0.3^{\mathrm{b}}$ & Traces \\
\hline & Panda & $12.7 \pm 0.1^{\mathrm{b}}$ & $245.4 \pm 18.7^{\mathrm{a}}$ & Traces & $2.8 \pm 0.1^{\mathrm{c}}$ & $7.3 \pm 0.3^{\mathrm{a}}$ & Traces \\
\hline \multirow[t]{3}{*}{ Pea } & Marych & $24.6 \pm 0.1^{\mathrm{c}}$ & $35.4 \pm 5.6^{\mathrm{a} . \mathrm{b}}$ & Traces & $2.1 \pm 0.2^{\mathrm{a} . \mathrm{b}}$ & $41.7 \pm 0.0^{\mathrm{c}}$ & $43.1 \pm 1.2^{\mathrm{c}}$ \\
\hline & Milwa & $23.4 \pm 0.1^{\mathrm{b}}$ & $28.3 \pm 1.9^{\mathrm{a}}$ & Traces & $2.3 \pm 0.0^{\mathrm{b}}$ & $35.9 \pm 1.4^{\mathrm{b}}$ & $36.8 \pm 1.2^{\mathrm{b}}$ \\
\hline & Wiato & $21.5 \pm 0.3^{\mathrm{a}}$ & $42.1 \pm 5.6^{\mathrm{b}}$ & Traces & $2.0 \pm 0.0^{\mathrm{a}}$ & $31.2 \pm 0.2^{\mathrm{a}}$ & $31.9 \pm 0.5^{\mathrm{a}}$ \\
\hline \multirow[t]{3}{*}{ Winter barley } & Bażant & $9.7 \pm 0.1^{\mathrm{c}}$ & $102.2 \pm 3.6^{\mathrm{a}}$ & $10.1 \pm 0.2^{\mathrm{a}}$ & $2.5 \pm 0.2^{\mathrm{a}}$ & $67.2 \pm 0.3^{\mathrm{a}}$ & $10.1 \pm 0.2^{\mathrm{a}}$ \\
\hline & Bursztyn & $9.0 \pm 0.0^{\mathrm{b}}$ & $119.3 \pm 1.1^{\mathrm{b}}$ & $25.8 \pm 0.2^{\mathrm{c}}$ & $2.6 \pm 0.0^{\mathrm{a}}$ & $74.7 \pm 0.9^{\mathrm{b}}$ & $11.2 \pm 0.1^{\mathrm{b}}$ \\
\hline & Gil & $8.5 \pm 0.1^{\mathrm{a}}$ & $100.9 \pm 0.4^{\mathrm{a}}$ & $19.0 \pm 1.4^{\mathrm{b}}$ & $2.5 \pm 0.1^{\mathrm{a}}$ & $67.5 \pm 0.4^{\mathrm{a}}$ & $10.8 \pm 0.7^{\text {a.b }}$ \\
\hline \multirow[t]{3}{*}{ Spring barley } & Blask & $9.5 \pm 0.1^{\mathrm{b}}$ & $87.2 \pm 16.6^{\mathrm{a}}$ & $12.1 \pm 1.0^{\mathrm{b}}$ & $5.2 \pm 0.1^{\mathrm{c}}$ & $70.9 \pm 1.6^{\mathrm{b}}$ & $14.9 \pm 0.3^{\mathrm{c}}$ \\
\hline & Boss & $11.4 \pm 0.0^{\mathrm{c}}$ & $86.3 \pm 0.5^{\mathrm{a}}$ & $6.5 \pm 0.4^{\mathrm{a}}$ & $3.4 \pm 0.1^{\mathrm{b}}$ & $57.3 \pm 0.2^{\mathrm{a}}$ & $12.1 \pm 0.6^{\mathrm{b}}$ \\
\hline & Bryl & $8.3 \pm 0.1^{\mathrm{a}}$ & $76.1 \pm 11.2^{\mathrm{a}}$ & $7.0 \pm 0.3^{\mathrm{a}}$ & $2.0 \pm 0.1^{\mathrm{a}}$ & $80.6 \pm 0.9^{c}$ & $8.0 \pm 0.4^{\mathrm{a}}$ \\
\hline
\end{tabular}

a, b, c, d Values in columns denoted by the same letters are not statistically different in analyzed cultivars at $p \leq 0.05$, values are mean $\pm \mathrm{SD}$ of triplicate

et al. [21] found similar contents of total phenolics in dehulled buckwheat (269 mg/100 g), although Zieliński and Troszyńska [23] showed a range from 164.7 to $408.2 \mathrm{mg} / 100 \mathrm{~g}$, depending on the type of solvent used for extraction. Tahir and Farooq [20] analyzed the buckwheat variety-dependence of polyphenol content and found that the total phenolic content varied from 770 to $1,660 \mathrm{mg} / 100 \mathrm{~g}$ d.m., depending on the variety. Both Borowski et al. [24] and Telesiński et al. [25] found polyphenol content in peas similar to that determined in this study. Wang et al. [26] examined the phenolic compounds in 17 pea varieties and found their content to range from 16.2 to $32.5 \mathrm{mg} / 100 \mathrm{~g} \mathrm{~d} . \mathrm{m}$. depending on the variety. Variety-dependence of the polyphenol content in peas was found by other authors [27-29]. Similar values of the phenolic content in barley to that determined in this study were found by Zieliński and Troszyńska [23]. They showed that phenolic content ranged from 55.1 to $111.8 \mathrm{mg} / 100 \mathrm{~g}$, depending on the extraction method. A number of studies have indicated the relationship between variety and polyphenol content [30-33].

The level of total phenolic content varied significantly $(p \leq 0.05)$ between cultivars (Fig. 1). It was the highest in buckwheat $(265.8 \mathrm{mg} / 100 \mathrm{~g})$ and the lowest in pea (35.2 $\mathrm{mg} / 100 \mathrm{~g})$, while the value for winter barley was $107.5 \mathrm{mg} / 100 \mathrm{~g}$ and $83.2 \mathrm{mg} / 100 \mathrm{~g}$ for spring barley. A similar relationship - a higher phenolic content in buckwheat than in barley-has been shown by other authors as well [21, 23]. They also found winter and spring barley to differ in this compound content. Many studies confirmed that the content of phenolic compounds depends on the type of analyzed sources [1, 4-6, 9, 12, 16, 32].
Phenolic Acids

Buckwheat grains contained traces of ferulic and vanillic acids, with the syringic acid occurring at the highest level $(7.3-19.1 \mathrm{mg} / 100 \mathrm{~g})$, followed by coumaric acid (2.1$2.8 \mathrm{mg} / 100 \mathrm{~g}$ ) (Table 1). Zieliński et al. [34, 35] also detected traces of ferulic acid in buckwheat but they found a lower level of coumaric $(0.135 \mathrm{mg} / 100 \mathrm{~g} \mathrm{d.m}$.) and syringic acid $(0.097 \mathrm{mg} / 100 \mathrm{~g})$, which may result from various features of analyzed samples and different analytical procedures $[5,6]$.

Seeds of all the pea cultivars contained traces of ferulic acid, which is in agreement with the results of Dueñas et al. $[7,36]$. The analyzed pea varieties contained similar levels of coumaric acid (ca. $2 \mathrm{mg} / 100 \mathrm{~g}$ ) and the content of syringic and vanillic acid changed to a similar extent

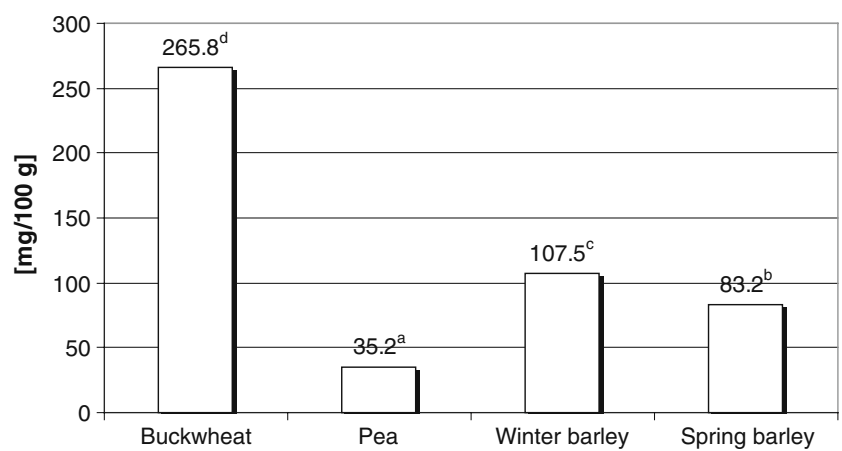

Fig. 1 Total phenolic content (expressed as catechin equivalent) in analyzed cultivars. Means denoted by the same letter for each cultivar are not statistically different at $p \leq 0.05$. Results are the means of nine measurements $(n=9)$ 
depending on the kind of varieties and ranged from 31.2 to $41.7 \mathrm{mg} / 100 \mathrm{~g}$ for syringic and from 31.9 to $43.1 \mathrm{mg} / 100 \mathrm{~g}$ for vanillic acid (Table 1). A lower level of coumaric acid was determined by Dueñas et al. [7] $(0.06 \mathrm{mg} / 100 \mathrm{~g})$ and Troszyńska and Ciska [37] (0.33 mg/100 g). Dueñas et al. [7] reported that peas contain $0.02 \mathrm{mg} / 100 \mathrm{~g}$ of syringic acid and $0.3 \mathrm{mg} / 100 \mathrm{~g}$ of vanillic acid, whereas Troszyńska and Ciska [37] determined their content in pea hulls at the level of $0.2 \mathrm{mg} / 100 \mathrm{~g}$ for syringic and 0.043 to $0.657 \mathrm{mg} /$ $100 \mathrm{~g}$ for vanillic acid.

Grains of barley contained the largest amounts of syringic acid $(67.2-74.7 \mathrm{mg} / 100 \mathrm{~g}$ in winter varieties and $57.3-80.6 \mathrm{mg} / 100 \mathrm{~g}$ in spring varieties) and the smallest amounts of coumaric acid $(2.5 \mathrm{mg} / 100 \mathrm{~g}$ in winter varieties and 2 to $5.2 \mathrm{mg} / 100 \mathrm{~g}$ in spring ones) (Table 1). Similar values of coumaric acid content were determined by Makarska and Michalak [38] (2.7-3.5 mg/100 g). Much lower values noted Zieliński et al. [34] $(0.05 \mathrm{mg} / 100 \mathrm{~g} \mathrm{~d}$. $\mathrm{m}$.), who also determined a very low level of syringic acid $(0.05 \mathrm{mg} / 100 \mathrm{~g}$ d.m.). Ferulic acid content in barley grains was found to range from 10.1 to $25.8 \mathrm{mg} / 100 \mathrm{~g}$ in winter varieties and from 6.5 to $12.1 \mathrm{mg} / 100 \mathrm{~g}$ in spring varieties. Similar contents were determined by Makarska and Michalak [38] (38.2-48.1 mg/100 g) and Kvasnička et al. [39] (37.1-43.4 mg/100 g). The amount of vanillic acid in barley ranged from 10.1 to $11.2 \mathrm{mg} / 100 \mathrm{~g}$ in winter varieties and from 8 to $14.9 \mathrm{mg} / 100 \mathrm{~g}$ in spring varieties. A similar content of this acid $(5.6-6.5 \mathrm{mg} / 100 \mathrm{~g})$ was found by Makarska and Michalak [38].

In conclusion, statistical differences $(p \leq 0.05)$ in ferulic acid content have only been found between the varieties of winter barley. Coumaric acid was a distinguishing factor for all the buckwheat and spring barley varieties. Syringic acid content was a distinguishing factor for all analyzed varieties within the cultivars (except for two varieties of winter barley) and vanillic acid occurred at a statistically different level $(p \leq 0.05)$ between all the pea and spring barley varieties (Table 1).

The analysis of inter-cultivars differences found ferulic acid levels exceeding the limit of quantification only in barley grains of both cultivars and was a distinctive factor for both (Fig. 2). These grains did not differ in the content of syringic and vanillic acids, but the content of these acids in the other analyzed cultivars was statistically different $(p \leq$ $0.05)$. Coumaric acid was a factor with the weakest distinctive force for individual cultivars because only grains of spring barley contained it at level statistically different $(p \leq 0.05)$ than in other materials.

It is noteworthy that the content of total phenolics determined using the spectrophotometric method in all pea varieties and some barley varieties was lower than the sum of phenolic acids determined by HPLC. This probably resulted from the fact that during the spectro-

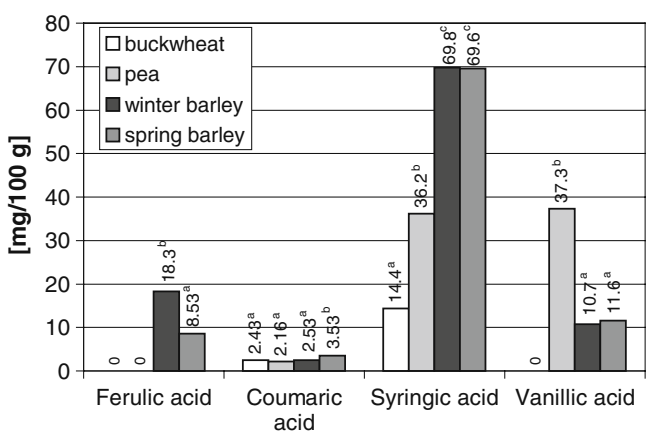

Fig. 2 The phenolic acid content in analyzed cultivars. Means denoted by the same letter for each cultivar are not statistically different at $p \leq 0.05$. Results are the means of nine measurements $(n=9)$

photometric procedure it was only possible to determine these phenolics which could be extracted with methanol (generally free phenolics forms) [5, 23]. On the other hand, the preparation of samples for determination of phenolic acids by the HPLC method involves acidic and enzymatic hydrolysis, where more phenolics could be released (e.g., bound into complexes with proteins and saccharides). Zieliński et al. [35] determined phenolic acids in buckwheat in two forms-free (extracted with $80 \%$ methanol and diethyl ether) and as esters (released by extraction with methanol followed by hydrolysis with $2 \mathrm{M}$ $\mathrm{NaOH}$ and extraction with ether). All the acids were present in much higher amounts as esters (the difference was tenfold for coumaric acid). The findings were confirmed by Madhujith and Shahidi [33].

It should be stressed that the differences in phenolic content observed by various authors could result from a variety of factors, including climatic conditions, agrotechnical procedures followed in cultivation and harvesting, ripeness of the material, harvest time, storage conditions, effect of genetic factors and varietiesdependent variability $[5,6]$. Hura et al. [40] reported that the content of phenolic compounds in buckwheat plants cultivated during two vegetation seasons may differ by a factor of 10. It should be especially stressed that the

Table 2 Correlation between analyzed discriminants

\begin{tabular}{llllll}
\hline & $\begin{array}{l}\text { Total } \\
\text { phenolics }\end{array}$ & $\begin{array}{l}\text { Ferulic } \\
\text { acid }\end{array}$ & $\begin{array}{l}\text { Coumaric } \\
\text { acid }\end{array}$ & $\begin{array}{l}\text { Syringic } \\
\text { acid }\end{array}$ & $\begin{array}{l}\text { Vanillic } \\
\text { acid }\end{array}$ \\
\hline Protein & -0.3941 & $-0.6211^{\mathrm{a}}$ & -0.3523 & -0.4702 & $0.8438^{\mathrm{a}}$ \\
Total phenolics & -0.1983 & -0.0620 & $-0.5803^{\mathrm{a}}$ & $-0.7999^{\mathrm{a}}$ \\
Ferulic acid & & 0.2920 & $0.7688^{\mathrm{a}}$ & -0.2079 \\
Coumaric acid & & & 0.2944 & -0.1441 \\
Syringic acid & & & & 0.0623 \\
\hline
\end{tabular}

${ }^{\text {a }}$ Correlation coefficient significant at $p \leq 0.05$ 
structures and properties of phenolics vary greatly, affecting extraction conditions and the analytical methods applied which, in turn, considerably affects the determined amounts $[5,6]$. Dueñas et al. [7] reported that releasing some phenolics by hydrolysis with various enzymatic preparations may result in hundred-fold differences in their concentrations. Sun and Ho [41] examined the effect of solvent applied on the total phenolic compound content in buckwheat grains. They found that it reached $900 \mathrm{mg} / 100 \mathrm{~g}$ when ethyl acetate was applied and 3,300 mg/100 g when acetone was used. Kivilompolo et al. [42] found that phenolic acid content may undergo a hundred-fold change depending on the measurement technique.

\section{Correlations}

Statistically significant relationships $(p \leq 0.05)$ have been found between protein content and the levels of ferulic and vanillic acids (Table 2). An increase in protein content in the material was accompanied by a decrease in ferulic acid amount and an increase in vanillic acid content. This may imply that ferulic acid was present in the material mainly as compounds with carbohydrates and vanillic acid with proteins. Reports by many authors have pointed to interactions between phenolics and proteins [18, 19, 43]. No statistically significant relationship has been shown to exist between the amount of protein and the total phenolics, which has also been confirmed by literature reports $[26,27,44]$.

Total phenolic content was in inverse proportion to the amount of syringic and vanillic acid. It probably resulted from the fact that these acids were present in forms which could not be extracted with $80 \%$ methanol. Oomah et al. [44] also observed a statistically significant negative correlation between some phenolic acids and their total content.

There was a positive correlation between ferulic and syringic acid, which suggests that they are present in similar connections with other components of analyzed products.

\section{Conclusions}

It can be concluded that the content of total phenolics can be useful as a distinguishing factor for all the cultivars analyzed in this study and for some of the varieties. However, individual varieties were best distinguished by the content of syringic acid. There were some significant $(p \leq 0.05)$ correlations between individual phenolic compounds and between phenolics and protein and, although these results are interesting, further investigations on larger sample populations are needed.
Open Access This article is distributed under the terms of the Creative Commons Attribution Noncommercial License which permits any noncommercial use, distribution, and reproduction in any medium, provided the original author(s) and source are credited.

\section{References}

1. Dimitrios B (2006) Sources of natural phenolic antioxidants. Trends Food Sci Technol 17:505-512

2. Iwai K (2008) Antidiabetic and antioxidant effects of polyphenols in brown alga Ecklonia stolonifera in genetically diabetic KK-A mice. Plant Foods Hum Nutr 63:163-169

3. Takahama U, Tanaka M, Hirota S (2010) Proanthocyanidins in buckwheat flour can reduce salivary nitrite to nitric oxide in the stomach. Plant Foods Hum Nutr 65:1-7

4. Yao LH, Jiang YM, Shi J, Tomás-Barberán FA, Datta N, Singanusong R, Chen SS (2004) Flavonoids in food and their health benefits. Plant Foods Hum Nutr 59:113-122

5. Grajek W (2007) Antioxidants in food (health, technological, molecular and analytical issues). Wydawnictwo NaukowoTechniczne, Warsaw (in Polish)

6. Naczk M, Shahidi F (2006) Phenolics in cereals, fruits ang vegetables: occurence, extraction and analysis. J Pharm Biomed Anal 41:1523-1542

7. Dueñas M, Estrella I, Hernández T (2004) Occurrence of phenolic compounds in the seed coat and the cotyledon of peas (Pisum sativum L). Eur Food Res Technol 219:116-123

8. Chon SU, Heo BG, Park YS, Kim DK, Gorinstein S (2009) Total phenolics level, antioxidant activities and cytotoxicity of young sprouts of some traditional Korean salad plants. Plant Foods Hum Nutr 64:25-31

9. Balasundram N, Sundram K, Samman S (2006) Phenolic compounds in plants and agri-industrial by-products: Antioxidant activity, occurrence, and potential uses. Food Chem 99:191-203

10. Yadav SK, Luthra YP, Sood DR, Aggarwal NK (2000) Gibberellic acid $\left(\mathrm{GA}_{3}\right)$ induced changes in proanthocyanidins and malt quality of two- and six-row husked barleys. Plant Foods Hum Nutr 55:87-96

11. Hernández-Borges J, González-Hernández G, Borges-Miquel T, Rodriguez-Delgado MA (2005) Determination of antioxidants in edible grain derivatives from the Canary Islands by capillary electrophoresis. Food Chem 91:105-111

12. Plessi M, Bertelli D, Albasini A (2007) Distribution of metals and phenolic compounds as a criterion to evaluate variety of berries and related jams. Food Chem 100:419-427

13. Irmak S, Jonnala RS, MacRitchie F (2008) Effect of genetic variation on phenolic acid and policosanol contents of Pegaso wheat lines. J Cereal Sci 48:20-26

14. Dinelli G, Carretero AS, Silvestro RD, Marotti I, Fu S, Benedettelli S, Ghiselli L, Fernández-Gutiérrez A (2009) Determination of phenolic compounds in modern and old varieties of durum wheat using liquid chromatography coupled with time-offlight mass spectrometry. J Chromatogr A 1216:7229-7240

15. Klepacka J, Fornal $Ł$ (2006) Ferulic acid and its position among the phenolic compounds of wheat. Crit Rev Food Sci Nutr 46:639-647

16. Ribereau-Gayon P (1972) Plant Phenolics. Hafner, New York

17. Pussayanawin V, Wetzel DL (1987) High performance liquid chromatographic determination of ferulic acid in wheat milling fractions as a measure of bran contamination. J Chromatogr 391:243-255

18. Rawel HM, Czajka D, Rohn S, Kroll J (2002) Interactions of different phenolic acids and flavonoids with soy proteins. Int $\mathrm{J}$ Biol Macromol 30:137-150 
19. Labuckas DO, Maestri DM, Perelló, Martínez ML, Lamarque AL (2008) Phenolic from walnut (Juglans regia L.) kernels: Antioxidant activity and interacions with proteins. Food Chem 107:607-612

20. Tahir I, Farooq S (1985) Grain composition in some buckwheat cultivars (Fagopyrum Spp.) with particular reference to protein fractions. Plant Foods Hum Nutr 35:153-158

21. Zieliński H, Honke J, Łatosz A, Troszyńska A, Ciska E, Waszczuk K, Szawara-Nowak D, Kozłowska H (1998) A rapid method for measurement of total antioxidant status of selected cereal grains-short report. Pol J Food Nutr Sci 7 (48):533-538

22. Chavan UD, Shahidi F, Bal AK, McKenzie DB (1999) Physicochemical properties and nutrient composition of beach pea (Lathyrus maritimus L.). Food Chem 66:43-50

23. Zieliński H, Troszyńska A (2000) Antioxidant capacity of raw and hydrothermal processed cereal grains. Pol J Food Nutr Sci 9/50 (3S):79-83

24. Borowski J, Szajdek A, Borowska EJ (2008) Chemical properties and biological activity of vegetables from the Olsztyn region. Bromatol Chem Toksykol 3:333-337 (in Polish)

25. Telesiński A, Kłódka D, Komsta A, Mroczek J (2009) Changes of the content of the ascorbic acid, the glutathione, flavonoids and phenolic compounds in chosen species of plants depending on the valency of the selenium added to the substrate (part IIDicotyledons). Ochr Sr Zasobow Nat 40:372-379 (in Polish)

26. Wang X, Warkentin TD, Briggs CJ, Oomah BD, Campbell CG, Woods S (1998) Total phenolics and condensed tannins in field pea (Pisum sativum L.) and grass pea (Lathyrus sativus L.). Euphytica 101:97-102

27. Zduńczyk Z, Godycka I, Amarowicz R (1997) Chemical composition and content of antinutritional factors in Polish cultivars of peas. Plant Foods Hum Nutr 50:37-45

28. Batish DR, Lavanya K, Singh HP, Kohli RK (2007) Phenolic allelochemicals released by Chenopodium murale affect the growth, nodulation and macromolecule content in chickpea and pea. Plant Growth Regul 51:119-128

29. Singh UP, Sarma BK, Singh DP, Bahadur A (2002) Plant growthpromoting rhizobacteria-mediated induction of phenolics in pea (Pisum sativum) after infection with Erysiphe pisi. Curr Microbiol 44:396-400

30. Maillard MN, Soum MH, Boivin P, Berset C (1996) Antioxidant activity of barley and malt: Relationship with phenolic content. Lebens Wiss Technol 29:238-244

31. Klepacka J, Fornal Ł, Konopka S, Choszcz D (2002) Relation between ferulic acid content in wheat coat, and milling quality and colour of grain. Electron J Agric Univ 5:http://www.ejpau.media. $\mathrm{pl} /$ volume $5 /$ issue $2 /$ food/art-15.html

32. Zhao H, Fan W, Dong J, Lu J, Chen J, Shan L, Lin Y, Kong W (2008) Evaluation of antioxidant activities and total phenolic contents of typical malting barley varieties. Food Chem 107:296304

33. Madhujith T, Shahidi F (2009) Antioxidant potential of barley as affected by alkaline hydrolysis and release of insoluble-bound phenolics. Food Chem 117:615-620

34. Zieliński H, Kozłowska H, Lewczuk B (2001) Bioactive compounds in the cereal grains before and after hydrothermal processing. Innov Food Sci Emerg Technol 2:159-169

35. Zieliński H, Michalska A, Piskuła MK, Kozłowska H (2006) Antioxidants in thermally treated buckwheat groats. Mol Nutr Food Res 50:824-832

36. Dueñas M, Hernández T, Estrella I (2007) Influence of the action of exogenous enzymes on the polyphenolic composition of pea: Effect on the antioxidant activity. Eur Food Res Technol 225:493500

37. Troszyńska A, Ciska E (2002) Phenolic compounds of seed coats of white and coloured varieties of pea (Pisum sativum L.) and their total antioxidant activity. Czech J Food Sci 20:1522

38. Makarska E, Michalak M (2005) Antioxidant activity of phenolic acids of spring barley. Annales UMCS Sec E 60:263-269 (in Polish)

39. Kvasnička F, Čopíková J, Ševčík R, Krátká J, Syntytsia A, Voldřich (2008) Determination of phenolic acids by capillary zone electrophoresis and HPLC. Cent Eur J Chem 6:410418

40. Hura T, Dubert F, Dąbkowska T, Stupnicka-Rodzynkiewicz E, Stokłosa A, Lepiarczyk A (2006) Quantitative analysis of phenolics in selected crop species and biological activity of these compounds evaluated by sensitivity of Echinochloa crus-galli. Acta Physiol Plant 6:537-545

41. Sun T, Ho CT (2005) Antioxidant activities of buckwheat extracts. Food Chem 90:743-749

42. Kivilompolo M, Obůrka V, Hyötyläinen T (2007) Comparison of GC-MS and LC-MS methods for the analysis of antioxidant phenolic acids in herbs. Anal Bioanal Chem 388:881-887

43. Naczk M, Grant S, Zadernowski R, Barre E (2006) Protein precipitating capacity of phenolics of wild blueberry leaves and fruits. Food Chem 96:640-647

44. Oomah BD, Campbell CG, Mazza G (1996) Effects of cultivar and environment on phenolic acids in buckwheat. Euphytica 90:73-77 